taking place either at the spring or autumn node for several years, and hence the greater necessity for continuous observation of the sun at the period named.

Extensive preparation has been made on the recommendation of M. Leverrier; the Astronomer-Royal availing himself of the telegraph, has notified observers at Madras, Melbourne, Sydney, and at Wellington and Canterbury, New Zealand, and we believe intends to organise a careful watch upon the sun's disc at the Royal Observatory, Greenwich. We know that a similar scrutiny will be carried into effect in American longitudes, so that it is not probable that a planet can present itself upon the sun on this occasion without being detected. Photography will be brought into requisition at more than one station. Where it is not available in the event of a planetary bedy being cletected, it will be necessary to determine the differences of right ascension and declination from the sun's limbs at frequent intervals as long as the object is projected upon the disc; from such observations carefully made the position of the orbit will be very approximately determined, and we should be enabled to follow up the new member of the solar system.

The New Observatory at Krel.-Prof. Peters has issued a brief description of the new observatory just erected a little to the north of Kiel, the present head-quarters of the Astronomische Nachrichten. The unfavourable position of the observatory at Altona, so long directed by Prof. Schumacher, and the desire to bring the establishment into nearer relation to the university at Kiel, led to successful negotiations about twelve years since for a suitable site near the town. The buildings were commenced in $187 \mathrm{I}$ and are now completed. There is a free horizon and a considerably better climate than at Altona, and no interruption from surrounding buildings.

The instruments in the new observatory include Reichenbach's meridian circle, formerly at Altona, which was so far improved by Repsold, as described in the Astronomische Nachrichten, that it may be considered a new instrument. The Repsold equatorial, also at Altona, is mounted in one of the smaller towers, and in another, a parallactically-mounted comet-seeker, to which is attached a 4 -feet refractor, its optical axis being parallel to that of the comet-seeker. Prof. Peters explains that the refractor being provided with a high power, may be usefnl in deciding whether any nebulosity caught up in the seeker is a comet, or a star-cluster.

About two months since, an equatoreally mounted refractor by Steinheil of Munich, with an object-glass eight Paris inches in diameter, was added, of the performance of which Prof. Peters promises details at a future date. The meridian circle is at present employed in the observation of all stars to the ninth magnitude, within $10^{\circ}$ from the pole, the same class of work, indeed, in which Schwerd and Carrington so long occupied themselves.

The position of the new observatory at Kiel is in longitude oh. $40 \mathrm{~m} .35^{\circ} 5$ E. of Greenwich, and latitude $54^{\circ} 20^{\prime} 29^{\circ} 7^{\prime \prime}$.

Besides its connection with the Kiel University, the observatory is also in relation to the Darish Marine, and contains facilities for testing the rates of chronometers at different temperatures, and a time-ball, apparently very similar to the one at our Royal Observatory, which is dropped at noon, mean time at Kiel.

65, OphuUchi (FL.).-Of this star Baily says, "Observed by Flamsteed on May 6, 169r, at 14h. rom. 58s, and regularly reduced by him. . . . But no such star is now to be found. It is neither Piazzi xvii. 308 , nor xvi. $25 \mathrm{x}$, as conjectured by that astronomer. Prof. Airy has been kind enough to look for this star, at my request, but has not been able to discover it." The place of this star, given in the British Catalogue, brought up to 1850 , is -

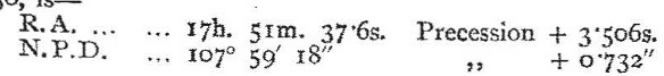

There is no star in this position in Argelander's southern zones, nor in the zones observed at Washington; neither is there any star in these zones with which it can easily be identified, on admitting any probable error of observation. Did Flamsteed observe an object of the class which we are accustomed to. term "new stars?" The Chinese annals record the appearance of an extraordinary star in the year 386 , which remained stationary from April to July in the same "sidereal-division" that 65 Ophiuchi would fall, and then disappeared. It may be worth while to watch any small stars near its position.

\section{BIOLOGICAL NOTES}

Flora of NEW GuineA, - Letters from Sydney of January 12 state that the Italian traveller, D'Albertis, had returned there from his last trip to New Guinea, and was engaged in preparing an account of his voyage up the Fly River. His fine collection of dried plants is in the hands of Baron von Mueller at Melbourne, who is describing many of the new plants in his "Papuan Flora." Among them is a grand Hibiscus, which Baron von Mueller has named Hibiscus albertisiz; its nearest affinity is with Hibiscus tupilifforus of Hooker, of Gua. daloupe and Dominica, in the West Indies. There is also a new Mucuna, which he has named Mucuna bennetti. D'Albertis describes this as one of the most beautiful of all the flowers seen in New Guinea ; it is abundant on the banks of the Fly River, and the pendulous masses of large red blossoms cover the loftiest trees from the base to the summit and form one of the most. gorgeous sights it is possible to conceive. There was also a yellow flowering species of the same genus which was rare, and only met with in the interior of New Guinea, in lat. $6^{\circ}$ south, on the banks of the Fly River. The flowers of this species were only seen $\mathrm{cn}$ the tops of the trees, forming a dense mass of blossoms, T'vre was likewise another species of Mucuna met with, bearing blue flowers. All these and a number of other novelties will duly appear in Baron von Mueller's forthcoming part of his "Papuan Flora."

SAlmo ARCTURUs. - We are informed that the Salmonoid brought home by the Arctic Expedition from Grinnell Land is a new species of Charr, described by Dr. Günther under the name of Salmo arcturns. It resembles in some points the Loch Killin Charr from Inverness-shire.

Prof. Ovsiannikoff on the Functions of the CereBELLUM, - In the seventh volume of the Mentoits of the St. Petersburg Society of Naturalists Prof. Ovsiannikoff communicates the results of experiments he has made in collaboration with M. Weliky on the physiological functions of the cerebellum. Preventing, by the tying of the carotid artery, the effusion of blood which ustally accompanies the cutting out of the cercbellum, Prof. Ovsiannikoff proved by a series of experiments that the last operation does not at all paralyse the co-ordination of motion. A rabbit remained alive during two weeks after all the upper half of the cerebellum was cut out, and did not show any traces of such paralysis, nor dia it lose its faculty of co-ordinating its movements after all the cerebellum was cut out, until an effusion of blood produced this result. A long series of varied experiments made by M. Ovsiannikoff on rabbits, pigeons, fishes, and frogs, confirms this result, as well as some wellknown pathological cases reported by Brown-Sequard, MIarc, Combetta, and others.

Fauna of LAKE GoKcha. - The seventh volume of the Memoirs of the St. Petersburg Society of Naturalists custains interesting information, by Prof. Kessler, on Lake Gokcha, lying in the Erivan government (Caucasus), at a height of 6,4 19 feet. It is surrounded with mountains from 9,000 to 12,000 feet high, and occupies about 660 square miles. Altogether its average depth is from 150 to 250 feet, reaching only in one instance $t$ 
36I feet. The lake has only a small and shallow outflow, the river Zanga, running into the Araks. The fauna of the lake and of its shores is varied. Spongiblce, not determined as yet, are very numerous. Among the Vermes the most common is the Nephelis vulgaris; the Crustacea are represented by a variety of microscopical forms and by a species of Gammarus, this species being probably all but the only representative of that kind, as the dredging was not pursued to depths greater than 150 feet. The snails are remarkably numerous, and all belong to species common in European iakes (Limnaus stagnalis, L. ovatus, L. varicularius, and Planorbis carinatus); they differ only by their unusually fine and brittle shales. The common frog (a local variety) and the Bufo viridis are numerous. The number of fishes is immense, but they belong to only five species, of which three are new. These three, which occupy an intermediate position between the Salno fario and the $S$. trutta and $S$. lanestris, will be described by Prof. Kessler under the names of Salno ischan, S. hegarkuni, and S. bolschac. The fourth species of fishes is very nearly allied to the Caboeta fundulus, Pall., a species most characteristic of Central Asian waters. The fifth is akin to the Barbus cyri, De Fillipi; it inhabits mostly the short and cold rivers running from the mountains.

ANTS. - Mr. McCook has recently brought before the Academy of Natural Sciences of Philadelphia, an account of his investigations on Formica rufa. He finds that ants descending the tree-patbs, with abdomens swollen with honey-dew, are arrested at the foot of the trees by workers from the ant-hill. The descending ant places its mouth in contact with that of the food-seeker, the two being reared on hind legs. Frequently two or three of its fellows are thus fed in succession by one ant, mostly complacentiy, but sometimes only on compulsion. Mr. McCook made many experiments, which lead to the conclusion that there is complete angity between the ants of a large field, embracing some $\mathrm{r}, 600$ hills, and many millions of creatures. Insects from hills widely separated always fraternised completely. A number of ants from various hills were placed in an artificial nest, and ham moniously built galleries and jointly cared for the cocoons.

NEiV Forms of HALIPHySEMA. - The second half of the second volume of Biologische Studien, by Dr. E. Haeckel, has just reached us. It contains an account of a wonderful family of minute forms belonging to the genera Haliphysema and Gastrophysema, and some supplementary remarks on the Gastrea theory. Six plates-illustrative of the new forms accompany this part. The genus Haliphysema was established by Bowerbank for $H$. tumanowicxii and $H$. ramulosum. The species described as $H$. echinoides seems almost certainly to be that described in 1870 , by Perceval Wright, as Wallichï, but the two new species described as $H$. primordiale and $H$. globigerind, the latter with a mosaic of Globigerina shells laid over it, are most extraordinary and interesting forms. The presence of a pore area in the tiny form figured in the previous note seems to points to its no having any close affinity to this new family of Haeckel.

\section{NOTES}

Prof. Sir C. Wryville Thomson, F.R.S., has been ap. pointed Rede Lecturer at Cambridge for the ensuing year. Sir Wyville Thomson will deliver a lecture in the Easter term.

A Botanical Congress assembles at Amsterdam on the rath of April.

THE Iron and Steel Institute meets in London on March 20 and following days On Wednesday, the $2 \mathrm{Ist}$, at the rooms of the Institution of Civil Engineers, Dr. Siemens, F.R.S., will deliver his inaugural address, and the Bessemer Medal will be presented to Dr. Percy. A number of important practical papers are set down for reading.
Capt. Allen Young has presented to the Museum of the Royal College of Surgeons a collection of the skulls of Esquimaux obtained by himself and the surgeon of his vessel, Mr. Horner, during the last cruise of the Pandora. The honour of knighthood has been conferred upon Capt. Young.

Srr JoHn Lubbock's Ancient Monuments Preservation Bill was, we are glad to say, read a second time in the House of Commons on Wednesday week. We hope none of its important provisions will be impaired in the select committee to which it has been referred, but that it will be passed essentially as it stands.

THE American Chemist for December, 1876 , contains an interesting Inaugural Address to the American Chemical Society on "Science in America," by Dr. J. W. Draper. The Address on a similar subject by Vice-President C. A. Young, at the last meeting of the American Association for the Advancement of Science, has been printed separately. In both addresses the important work done by Americans in various departments of science is justly insisted upon, and the future of science in America spoken of in hopeful terms. Men of science in England, we are sure, will heartily endorse all that Professors Draper and Young claim on behalf of their countrymen as original workers in science, and there is every reason to believe that there is a bright future for science in America.

As soon as the news that Mr. Edward, the Scottish Naturalist, had resigned the curatorship of the Banff Museum spread over the country, he was pressed to accept various situations, among others one in Aberdeen and another in Durham, the latter in the University of that city. He has been obliged to decline all these offers owing to the state of his health. He had been solicited by the Meteorological Society of London to become one of their observers. This request he had owing to the same cause declined. The work is, however, congenial, and does not demand a change of residence, and we believe be has yielded to a second very pressing application.

THE Sedgwick Prize, founded in honcur of the late Prof. Sedgwick, for an essay on a geological subject, has been adjudged to Alfred John Jukes-Browne, B.A., of St. John's College, Cambridge. The subject of the essay is "The Post-tertiary deposits of Cambridgeshire, and their relation to deposits of the same period in the rest of East Anglia." The subject for the Sedgwick Prize to be awarded in 1880 is the best essay on "The Fossils and Paleontological Affinities of the Neocomean Beds of Upware, Wicken, and Brickhill." The prize is open to the competition of all graduates of the University of Cambridge who have resided sixty days during the twelvemonth preceding the day the essays must be sent in, that is, before October 1,1880 .

A PRELIMINARY meeting has been held in Paris by some influential followers of the Positive Philosophy for the purpose'of esta. blishing a course of lectures according to the system of Auguste Comte, as modified by Littré. Important resolutions were passed as to the teaching of the several sciences which, according to the theoretical view adopted by Comte, constitute the encyclo. pedic education. At the next meeting resolutions will be proposed for meeting the expenses of the institution and regulating its administration.

AN arrangement has been made with the Cassel publisher, Theodor Fischer, whereby the hitherto very expensive publication Palcontographica, will be published in yearly volumes at not more than forty-five shillings each.

THE Balloon Commission of the French Government, styling itself "Commission pour les Communications par Voie Aérienne," has become a standing institution, and includes within its province carrier pigeons as well as aronauts and balloons. 